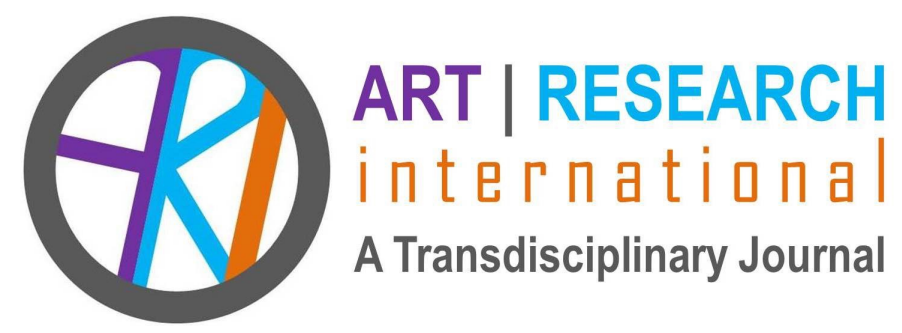

\title{
SOCIAL PRACTICE AS ARTS-BASED METHODOLOGY: EXPLORING PARTICIPATION, MULTIPLICITY AND COLLECTIVE ACTION AS ELEMENTS OF INQUIRY
}

\author{
Lynn Sanders-Bustle \\ University of Georgia \\ bustle@uga.edu
}

Lynn Sanders-Bustle is Chair and Associate Professor of Art Education at the University of Georgia in the US. She is editor of the book, Image, Inquiry, and Transformative Practice and has published in Studies in Art Education, Canadian Review of Art Education, the Journal of Adolescent and Adult Literacy, the International Journal of Education and the Arts, and Art Education. Creative projects include the installation of large-scale mosaics in Virginia and Louisiana and social practice implementations in community and public-school settings in Georgia. Her research focuses on socially engaged art, community-based art education, service-learning, and teacher preparation.

\begin{abstract}
Claims that the arts are a kind of research is nothing new, finding relevance for scholars in the social sciences and the arts (Barone \& Eisner, 2011; Cahnmann Taylor \& Siegesmund, 2018; Leavy, 2019, 2009; Sullivan, 2005). Given that art is continuously being reimagined, it follows that arts-based research takes into account contemporary artistic processes and materials and the theories, aesthetic philosophies and contexts that shape them. In this paper, this author considers socially engaged art in the context of arts-based research and raises the question, what can be learned from social practice as an arts-based methodology? The work of three socially engaged artists are referenced to demonstrate how distinct qualities associated with social practice, such as shared participation, multiplicity, and collective action offer new considerations for arts-based research that aims to bring about social change.
\end{abstract}


Key words: socially engaged art; social justice; arts-based research; qualitative research; post qualitative research 
In a public square in Lima, Peru, located just next to government buildings, passersby interact with 5-foot pieces of white chalk by making marks on the sidewalk below or breaking off pieces to write words of protest. In a village in India, Dialogue, a collective of artists, works with community members to resolve problems associated with a leaky and unsanitary water pump (see Figure 1). In a Toronto classroom, sixth-graders explore social issues such as trade, consumption, and child exploitation with two artists, through the making of chocolates. These projects are among many socially engaged art implementations being initiated world-wide by contemporary artists. Unlike art created by a single artist, socially engaged art or social practice is participatory in nature and aims to create social change through the cultivation of new social forms (Frasz \& Sidford, 2017; Sholette \& Bass, 2018). In this article, I consider how the relational intentions of social practice artists might be investigated more fully as a kind of arts-based research and in doing so highlight intersections with the arts-based methods utilized in both qualitative and post qualitative research.

To date, much discussion related to arts-based research centers around the arts' relationship to a range of research methods and methodologies (Barone \& Eisner, 2012; Cahnmann-Taylor \& Siegesmund, 2018, 2008; Leavy, 2009, Knowles \& Coles, 2008; Wang, Coemans, Siegesmund, \& Hannes), the arts potential to uncover nuance, develop empathy and critical consciousness (Finley, 2014) and reveal new knowledge not realized using traditional research methods. jagodzinski and Wallin (2013) suggest that because much artsbased research is situated within existing systems of academic thinking and action, a new ethics of betrayal is needed through which research is shifted from "an information society to an in-form-ation society, from being to becoming, from knowing the world to being in the world as one 'object' amongst many, and one species amongst many species: privileged certainly, but radically centered" (p. 17). This perspective is also echoed by scholars who consider the arts as a remedy for the problem of methodology in post qualitative research (Holbrook \& Pourchier, 2014; Rousell, 2019). Relatedly, Rousell (2019) pointedly argues for "a more robust engagement with the aesthetics and the ontology of art, with a focus on the particular potential of art as a relational mode of production and experimentation that is distinct from philosophy and social science" (p. 2). Regardless of perspective, it is safe to say that arts-based research is expanding and conceptualizations of such work are changing to align with emerging epistemologies and ontologies.

As researchers contend with the ever-changing landscape of arts-based research, contemporary art continues to evolve to reflect the activist and social aspirations of artists. Therefore, it follows that arts-based researchers take into account how emerging artistic processes, materials, theories, and contexts might inform arts-based research, and in doing consider how qualities associated with social practice such as an increased attention to participation, collectivity and social change might overlap with and extend existing artsbased research practices and, perhaps, inspire new ways of thinking through theory (Jackson \& Mazzei, 2012). In this spirit, Cahnmann-Taylor and Seigesmund (2008) point out, 
"new forms that challenge traditional conceptions of research, can also change 'the rules of the game;' and whenever the rules of the game change, there is the possibility of new outcomes on the playing field" (p. 4).

The impetus for this article comes from my current challenge as a teacher educator/ scholar/artist to navigate the problematic space between qualitative and post-qualitative methods in arts-based research. As someone who is interested in understanding the potential for social practice in the context of teacher preparation, I struggle to identify those processes or methods that can help me think through arts-based research as a collective endeavor that foregrounds social interaction as an aesthetic form. For three years as a university art educator, I have collaborated with preservice teachers and school communities to create socially engaged art in public school settings in the US (Sanders-Bustle, 2018, 2019). Specifically, I am interested in learning if and how socially engaged art might animate the publicness of schooling by opening new social spaces through which school communities can participate more fully in their rights as citizens to benefit from a just and fair education.

During my time as a teacher educator, I collaborated with preservice teachers on multiple projects that asked us to critically consider the co-creation of social forms as a kind or transpedagogy, that is a blending of art and pedagogy outside of traditional academic structures (Helguera, 2011). Described as social sketches, these efforts have evolved over time, starting as what might be best be likened to interventions in commons spaces (Sanders-Bustle, 2018, 2019) in a middle school, to current work at a high school that aligns more closely with the participatory and community-driven aims of socially engaged art. Informed by strategies employed by socially engaged artists, the need to collaborate has fostered a greater awareness of the social issues that matter to students, the importance of participation, distributions of power, and our emerging transpedagogies, or the blending of educational and educational processes outside of unconventional formal art education (Helguera, 2011; Thorne, 2017).

Our efforts challenged the relevancy and ethics around the art experiences we facilitated and disrupted conventional trappings and structures associated with teacher preparation, curriculum, and schooling, and in doing so, revealed a greater need for tolerance with ambiguity, risk, and failure in teacher education. Of importance to me is finding ways to not only better understand and elevate pedagogy/art and inquiries, but to locate new ways to activate thought, through yet-to-be-known artistic problems and provocations. Like others (Irwin \& Springgay, 2008; Springgay, Irwin, Leggo \& Gouzouasis, 2008), I do not view research, pedagogy, and art as separate and distinct, but as entangled entities that collectively speak in new ways and shape thinking, making, and doing as states of becoming. Therefore, throughout this paper, the terms, art and research will coalesce in varying configurations based on the moment of the discussion. 


\section{Making Art/Research Social Practice}

The ideas that I propose in this article are informed by the historical and contemporary context surrounding social practice, which I will briefly share in this section. While socially engaged art is widely discussed by scholars, critics, and artists, qualities used to describe social practice vary and continue to be debated. Relational, participatory, and other forms of socially-situated works emerged in the 1990 s as an alternative to preoccupations with object, autonomy, institutional conventions, capitalism, and technology. Part of a larger participatory turn in contemporary art, Claire Bishop (2006b) described this notable shift as a "a surge of artistic interest in collectivity, collaboration and direct engagement with specific social constituencies" (p. 178). Dismantling modernist conceptions of artistic/authorial practice focused on the production of art objects and aimed at rehumanizing "a society rendered numb and fragmented by the repressive instrumentality of capitalist production" (Bishop, 2012, p. 11). Participatory works are referred to using a range of terminologies such as new genre public, dialogical, littoral, socially engaged and cooperative art (Finkpearl, 2013; Helguera, 2011; Kester, 2004; Lacy, 1995). This participatory shift dramatically redefined what it means to make art, calling for new skills and processes as artistic motivations and intentions shifted from the individual to the collective with aims to intervene, disrupt, and create social change.

Like other socially situated art practices, socially engaged art has been influenced by avant-guarde provocateurs such as situationist Guy Debord (1967), Joseph Beuys (1973) and Allan Kaprow (1966), the social movements of the 1960s, and critic and curator Nicolas Bourriaud's (1998) theory of relational aesthetics. Bourriaud made the case for relational art as "a set of artistic practices which take as their theoretical and practical point of departure the whole of human relations and their social context, rather than an independent space" ( $p$. 113). Not without critique, his aesthetic theory introduced language for talking about art that is not symbolic, but rather, focused on social interaction through everyday practices. However, unlike some forms of relational art, socially engaged art is distinct in its "aims to improve conditions in a particular community or in the world" (Frasz \& Sidford, 2017, p. 4). According to Sholette and Bass, (2018) social practice,

is not merely to make art that represents instances of sociopolitical injustice (consider Picasso's Guernica), but to employ the varied forms offered by the expanded field of contemporary art as a collaborative, collective, and participatory social method for bringing about real-world instance of progressive justice, community building, and transformation. (p. xiii)

In other words, unlike modernist conceptions of art, socially engaged art focuses on the making of social change, not the making of an object. Artists are less concerned with art as a fixed object or commodity, but rather work toward "something breathing, performative, and 
action based...the qualities of which are anti-representational, activated through participation, political, and situated in the real world" (Thompson, 2012, p. 21).

Although the qualities of socially engaged art, such as audience participation, shared authorship, dialogue and collective action, have been explored by art critics and scholars (Bishop, 2012; Finkpearl, 2013; Helguera, 2011; Jackson, 2011; Kester, 2011) as well as art educators (Carpenter, 2014; Irwin \& O’Donoghue, 2012; Kalin \& Barney, 2014; SandersBustle, 2018; Schlemmer, Carpenter \& Hitchcock, 2017), less research has focused on socially engaged art as a kind of arts-based research. Interestingly, many social practice artists are looking to qualitative methodologies used by ethnographers, sociologists, or anthropologists (Kester, 2011; Finkpearl 2013) to assess the impact and ethical rigor of their work. It could be argued that goals for socially engaged art, aimed at the realization of social justice and equity, intersect with the theories, epistemologies and methodologies found in critical arts-based research. Finley, Vonk and Finley (2014) describe critical artsbased research as "a methodology for ethical research that is futuristic, socially responsible, and useful in addressing social inequities" (p. 620). Like social practice artists, critical artsbased researchers believe that the purpose of their work is to challenge dominant ideologies and promote social justice and equity through artmaking. Like socially engaged artists, critical arts-based researchers take into account the ethical dimensions of their practice and the role that dialogue, empathy, and care play in the decisions they make as artists and researchers (Finley, Vonk \& Finley, 2014). Yet, an important distinction can be made here. In the case of some critical arts-based research, traditional art mediums serve as catalysts for democratic and social just ways of being, while in the case of socially engaged art, traditional art mediums are secondary to artists' desires to create what Thompson (2012) refers to as living forms or work that is "breathing, performative, and action based" (p. 21). In other words, the creation of new social forms is the goal, and the quality of these forms take precedence as dialogue, active listening, and the sharing of everyday tasks function as mediums. Finally, recognizing the fluid, emergent and relational complexity of their practice as artists/researchers, some recognize the value of post qualitative approaches for thinking through relational art projects (Irwin \& O’Donoghue, 2012; Springgay, 2013; Springgay \& Zaliwska, 2015).

In this paper, I do not make a case for either qualitative or post qualitative arts-based research, but rather discuss points of intersection between the processes social practice artists use and those used by arts-based qualitative researchers and more broadly, qualitative researchers. To do so, I use the works of socially engaged artists first referenced in the introduction of this paper as a starting point for this discussion. The first, Chalk, by artists, Jennifer Allora and Guillermo Calzadilla (2019), began as an interest in mark making and grew into a series of socially engaged works implemented in Lima, Peru, Paris, France, and Sydney, Australia. In each, the artists placed 6-foot long columns of chalk in public squares encouraging participants to engage socially and politically with the city. Like many socially engaged works, Chalk is interventionist, invites voluntary participation from 
passersby, and is fluid, shifting over time, based on interactions without and an end product in sight.

The second, The Nalpar or Water Pump Site is one part of a series of works created by Dialogue, a collective of artists working in Kondagaon, India (see Figure 1). A carefully chronicled example of dialogic art (Kester, 2011), the series was initiated in 2002, by Navjot Altaf, Rajkumar, Shantibai, and Gusseruram. Nalpar was collaboratively designed and implemented to solve problems related to the daily pumping and carrying of water which was, for the most part, carried out by Adivasi (India's indigenous people) women and children, and critical to rice cultivation in the village. A smooth concrete structure, the water pump site features Adivasi cultural symbols of water and provides a system aimed at channeling off and collecting water for irrigation while doubling as a social space. This project is a particularly strong example of social practice, because of the attention given to honoring the indigenous cultural heritage of the Adivasi, while involving community members at all levels of the project over a sustained period of time.

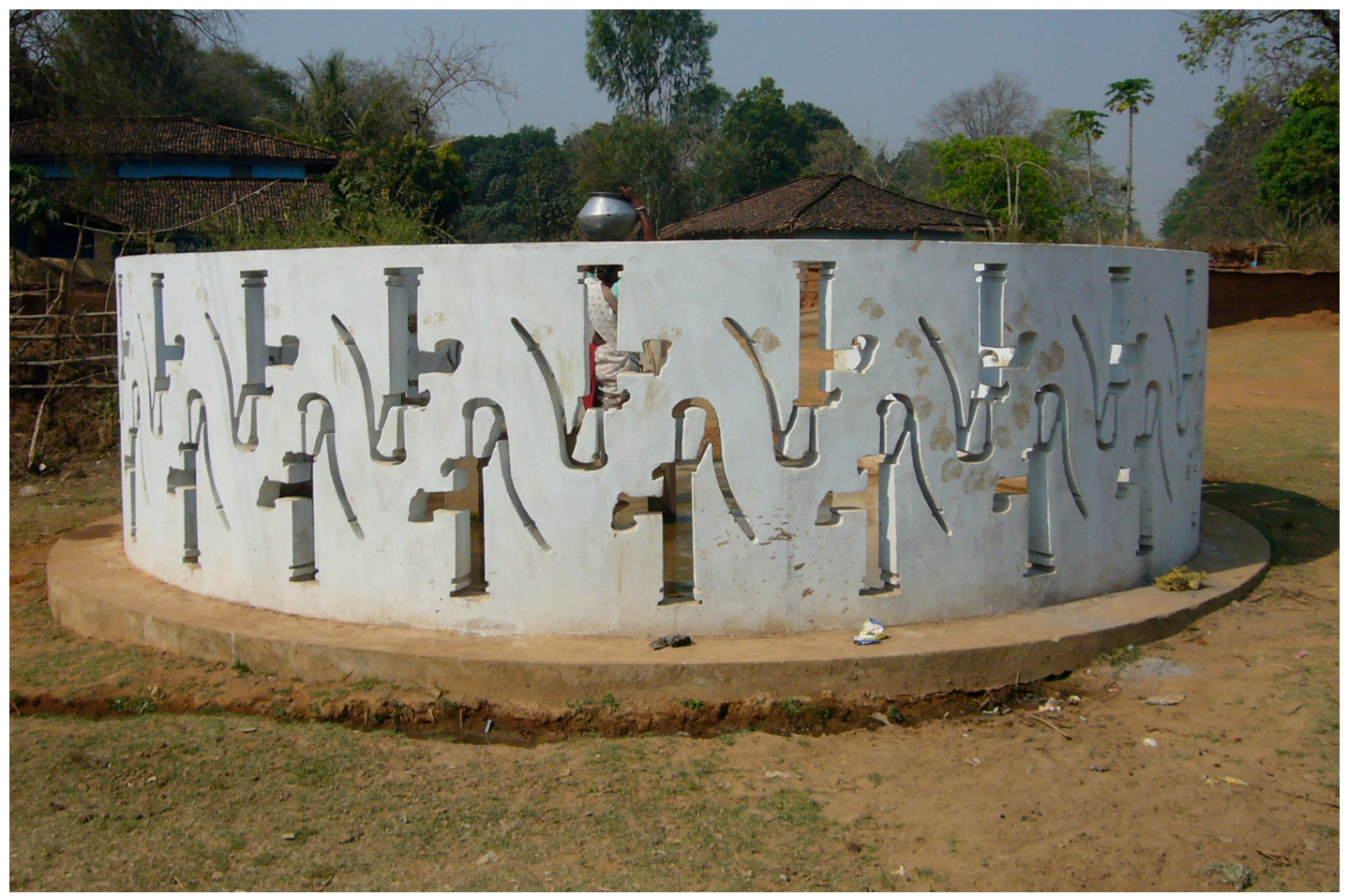

Figure 1: Nalpar Water Pump, reprinted with permission from Grant Kester

Finally, pedagogical in nature, The Ask Me Chocolates project, implemented by artists Hannah Jickling and Helen Reed (2018), involved sixth graders enrolled in a Toronto public school, in a collaboration focused on topics related to international trade and labor which ranged from cacao production to child exploitation (see Figure 2). 


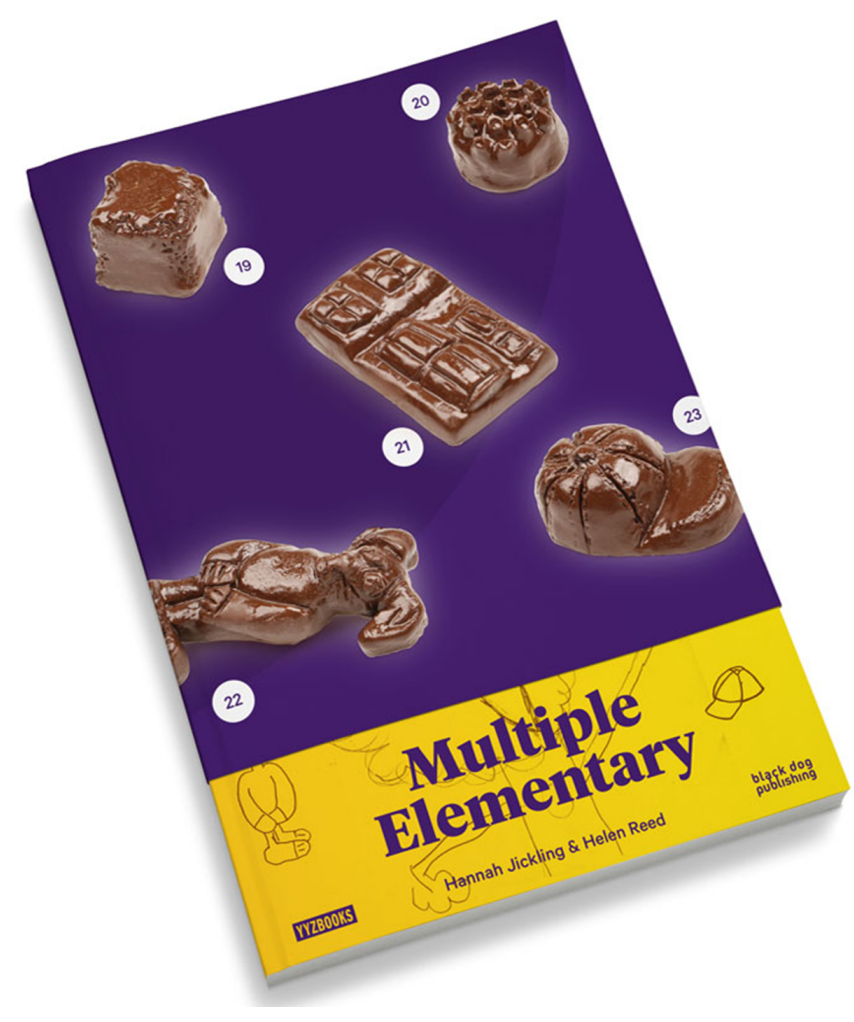

Figure 2: Ask Me Chocolates, reprinted with permission from Hannah Jickling and Helen Reed

\section{Participation, Deskilling, and Multiplicity in Social Practice/Research}

In the contexts of the aforementioned works, I asked, what opens up when we think about socially engaged art as a kind of arts-based research that is not only critical and emancipatory in aim, but collective in intention and formation? To answer this question, I use three key qualities of social practice: participation, deskilling, and multiplicity to organize my discussion. It is important to note that these qualities signify a shift away from the idea of an individual artist/researcher creating a single object to be shared with a viewer, to that of a new living form collectively designed for social change. The emphasis is no longer on the art as an object, but rather on the alternative social exchanges that emerge through participation with others.

\section{Participation}

A heightened concern for participation and shared authorship are key aims of social practice artists as participation involves a collective reaction and an ameliorative response that requires artists to carefully consider their relationships with their participants and the 
ethical, political, and aesthetic qualities of social interaction as an aesthetic form. As early as 1995, Suzanne Lacy, founder of New Genre Public Art, saw the need for a framework for thinking about audience participation, representing it as a non-hierarchical series of six permeable concentric circles in which groups of people assume different responsibilities for a shared art experience. Taking into account the dynamic energy of participation and relationships among kinds of participation, circles of participation include origination and responsibility, collaboration and co-development, immediate audience, and audience of myth and memory. More recently, Helguera (2011) described a multi-layered participatory structure for participation that ranges from nominal participation in which the participant offers limited participation that is passive in nature to collaborative participation in which the participant shares responsibility for the design and implementation based on community need. The latter, collaborative participation, best describes the intentions of socially engaged artists to involve participants more fully as collaborators in the interest of collective action, recognizing that social change can only happen in concert with others.

Concerned about the relational quality of their work, many social practice artists recognize the value of qualitative research methods such as interviews, focus groups and participant observations (Finkpearl, 2013; Helguera, 2011; Kester, 2011). While these are not considered arts-based methodologies, they are often utilized alongside or in conjunctions with art processes. Of particular interest to socially engaged artists might be practices associated with Participatory Action Researchers (PAR). Like social practice, PAR is participatory in nature and is designed to promote meaningful social change through collective inquiry and a political approach to knowledge making (Brydon-Miller \& McGuire, 2009; Brydon-Miller, Maguire, Noffke, \& Sabhlok, 2011; Irizarry \& Brown, 2015). Integral to PAR is the positioning of participants as co-researchers in the interest of "transformative personal, organizational, and structural change" (Brydon-Miller \& Maguire, 2009, p. 79). In many instances, PAR involves research participants as co-researchers in a range of arts processes such as poetry, drawing, mapping or photography (Burke, Greene, \& Mckenna, 2016) to help participants "identify, represent, and enhance their community" (Wang \& Burris, 1997, p. 389). Photovoice, is one method which is widely used by PAR researchers. According to Wang (1999), by taking photographs, participants are able to record and reflect on community strengths, promote critical dialogue and knowledge, and communicate issues to policy stakeholders. While this method does give a participant an opportunity to, essentially collect and interpret data based on personal interest, the taking of photographs may or may not involve collaboration with others therefore failing to shape a collective response or action. However, this is not to say that photovoice does not involve opportunities for dialogue and the co-researcher inquiries. At the same time, it is important to note that while art methods may be incorporated into research, art methods that utilize conventional art processes and materials, like other qualitative methods, bring with them institutional structures, systems, histories, and contexts, which often function as roadblocks to new lines of thought and the emergence of new processes and alternative social exchanges. Unlike PAR researchers who use art (e.g. photography) as a method and/or data, socially engaged 
artists consider participation and the collective making of a social form as a living, aesthetic/ research form, in and of itself. Its formation is completely dependent upon collectivity and is not distinct from the intentions of the artist/researcher. Ironically this is where the motivations of social practice artists and some PAR researchers diverge to a certain extent. Many (not all) social practice artists seek what Helguera refers to as "collaborative participation" (2011, p. 15) from the start of a project encouraging a fluid, yet-to-be known, unfolding series of situations from which new forms of sociability take shape. In the end, the ever-evolving social form, not object, can only emerge in formation with others.

Given that the formation of new social exchanges is integral to social practice, it makes sense that artists carefully consider the quality of dialogical processes (Kester, 2011) introduced as part of their practice. Kester claims that through social practice, dialogue is "reframed as an active, generative process that can help us speak and imagine beyond the limits of fixed identities, official discourse, and the perceived inevitability of participant political conflict" (2011, p. 8). Here, dialogue serves as a medium through which convention and status quo are challenged as new social forms emerge. Earlier, Kester (2004) described what he referred to as a dialogical aesthetic made up of two key interrelated elements, which include the importance of developing "a strong understanding of social context from which others speak, judge, and act" (p. 112), and "redefining discursive interaction in terms of empathetic identification" (p. 115). Based on this, art/research becomes an interrelated process for not only understanding contexts, but a kind of social action through which empathy is developed through dialogue as a medium for social change.

In the case of Nalpar, the artist collaborative Dialogue's creative philosophy is built around the role that dialogue plays in developing reciprocity between the artist/s and the community through the planning and creation of spaces as well as "the forms of social interaction catalyzed by their subsequent use" (Kester, 2011, p. 78). Described by Lather (1986) as the "mutual negotiation of meaning" (p. 286) developing reciprocity has long been considered important in qualitative research, especially scholarship aimed at the advancing emancipatory knowledge. Key considerations for some scholars have been to better understand the dynamics of reciprocity and to achieve maximum reciprocity through ongoing attention to dialogue and negotiation in all phases of research as well as the involvement of participants in the construction of knowledge (Fay, 1977). Critical to Nalpar's success was the artists' commitment to achieving reciprocity through sustained dialogue with the Adivasi population. Dialogue was essential for developing social interactions needed to remedy problems associated with water collection, while making sure that visual details integrated into design served as relevant and powerful signifiers of the Adivasi culture. This required the artists to learn more about the indigenous community and the ways that the culture has been appropriated and commodified and, in the interest of fostering a dialogic aesthetic, to develop empathy and concern about the wellbeing of participants. For over a decade, Dialogue artists have spent a considerable amount of time in Kondagaon coming to 
understand village life, the seasonal cycles associated with rice farming and craft traditions associated with spiritual and cultural traditions, which were being exploited by outsiders.

Like many artists/researchers who seek social change, the quality of dialogue is paramount to the decisions they make in concert with others. In an introspective investigation of their research, Oliver and Badham (2013) describe the importance of developing dialogue in their research with residents of Bell Bardia estate, a small housing estate in Melbourne, Australia. There, they co-created a project called, "Stories from Home" involving residents in a range of art installations, communal events, and a final exhibition. The activities were designed to combat the stigmatization of residents associated with their status as low income, working class migrants who had recently moved into the community. By examining their own research/art practice as ethnographic conceptualism, Oliver and Badham came to better understand the limitations of methods and discovered potential for a kind of reflexivity that extends beyond writing one's self into a text or involving participants in an artifact, to a kind of reflexivity shaped by "visiting and spending time in the community, being part of the everyday, listening and seeing, waiting for what dialogues and art making would emerge" (p. 161). Oliver and Badham's use of "ing" to describe the emergent quality of dialogue can be likened to how social practice, as a kind of research, presses up against the institutional structures of qualitative research and in doing so calls for alternatives that align with the collective spirit of making more socially just relational forms in concert with others. This suggests the need for research methods that take into account fluidity, ambiguity, and uncertainty, which are not always valued to the fullest degree in some artbased qualitative research that asks for data, findings, results, and conclusions.

In this regard, one might argue that post qualitative research might offer alternative ways to think about dialogue beyond that associated with human language. For example, Jackson and Mazzei (2013) contend that voice and agency should not attributed to the individual, but rather be understood as an entanglement of the human and the non-human. Still largely human-focused and human-directed, socially engaged artists might look more closely at post-human theories that more broadly consider entanglements and intra-actions (Barad, 2007) that bring attention to life's complexities throughout human, non-human and more-than human fields of activity (Manning \& Massumi, 2014). Such attention might inspire new thinking about what it means to participate or be in "dialogue" with one another (human or otherwise) as proposed by Hultman and Taguchi (2010) in their description of "the intraaction between the girl and the sand" (p. 530), whereby both are theorized as a state of becoming with one another. This idea might be considered in the context of Chalk whereby the chalk is in a state of becoming with the person who draws with it and the person is in a state of becoming with the chalk, begging the question, what happens to social practice, when the larger entanglements are considered? With this question, in mind, post qualitative research may inspire social practice methods that encourage artists to consider larger ecologies when thinking about the nature of social justice and equality in a human centered world. 


\section{Crossing Boundaries and Deskilling}

With increased interest in improving social conditions through dialogue and action and a desire for ethical practice, social practice artists often look to other disciplines such as sociology, education, anthropology, and geography (to name a few) to make better informed decisions about their work (Helguera, 2011; Kester, 2004, 2011). In such instances, artists are required to deskill, that is to break free from, processes and materials most often associated with artmaking/researching. Helguera asserts that deskilling art is a necessary process through which artists unlearn established art curricula (sculpture, painting, ceramics) and reimagine the curriculum as multidisciplinary, responsive to the needs of others, and experiential. For example, social practice artists foreground the development of interpersonal and leadership skills not typically associated with artmaking such as focused listening, thoughtful dialogue, and community planning (Pasternak, 2012). With this in mind, social practice artist, Fiona Whelan (2018) offers listening workshops to artists that highlight, "components of meaningful engagement, including trust, risk, group dynamic, attention to power relationships, self-reflexivity, and facilitation skills, while bringing to the fore the politics of voice and listening" (p. 33). Lacy (1995) suggests that a comprehensive set of skills is needed, asserting that social practice artists learn,

how to collaborate, how to develop multilayered and specific audiences, how to cross over with other disciplines, how to choose sites that resonate with public meaning and how to clarify visual and process symbolism for people who are not educated in art. (p. 177)

Deskilling is also necessary for shared authorship to be realized. An ongoing negotiation, shared authorship, cannot be achieved if researchers/artist's skills are valued over participant's skills or if skills are differentiated as high or low. Nor can viewers/ participants take on passive roles deferring to the artist/researcher or accepted institutionalized structures for how to participate. Furthermore, socially engaged art takes into account the aesthetic potential of day-to-day (non-art) activities in public spaces that are not traditionally associated with artmaking or art spaces such as galleries and museums and instead involve participation in activities such as talking, making a meal, moving around and shopping. de Certeau (1984) describes these activities as tactical in nature, that is, they operate outside of the institution, allowing for varied, sometimes subversive or interventionist ways of operating, and in doing so validate the contributions of many. Chalk takes advantage of the everyday quality of the public square, temporarily attracting and distracting passersby and inviting their unique skills as they make choices about how and with whom they participate. Social interaction emerges based on interests and unanticipated skills brought to the project and relate not only to participants' abilities to use chalk in a certain way, but to skills related to political interest, civic engagement, happenstance and to the dialogue (convivial and antagonistic) that takes shape. Furthermore, the absence of the 
artists as facilitators, in many ways, validates assets collaborators bring to the shaping of the work.

Like socially engaged artists, post qualitative researchers value the deskilling of art/ research, longing for fluid "methodologies without methodology" (Koro-Ljungberg, 2016, p. 1) that might be enabled by looking beyond human-centered research to processes explored in new materialism, post-humanism, affect theory and others (St. Pierre, 2015; Jackson \& Mazzei, 2012). Yet, among post qualitative researchers, discrepancies exist as to the relationship between theory and arts-based practice. According to Roussel, some researchers see alignments between arts and post qualitative research (Sinner, 2017), while others, such as jagodzinki and Wallin (2013) highlight incompatibility between radical posthuman ontologies and what they count as arts-based research. For Roussel, most post qualitative research operates from a hylomorphic understanding of art built around the superiority of man over nature (Rousell \& Fell, 2011). This perspective, may or may not apply to social practice depending on the kind of change artists hope to see in the world and the extent to which the human is decentered and the more-than-human considered.

\section{Multiplicity, Documentation, and Representation}

Although social change serves as a motivating factor for socially engaged art, opening up art/research to collaborative participation requires letting go of individual authorship and asks artists/researchers/teachers to consider the multiples in art/research/ pedagogy (Jickling \& Reed, 2018). This attention to multiples extends across processes as collective forms of participation are employed and the fixed boundaries of documentation and representation continuously shift, or are erased and/or altered through interactions with others. The need to take into account the emergent and relational qualities of inquiry is taken up by post qualitative researchers who recognize that data is partial, methods restrictive and analysis often simplistic (Jackson \& Mazzei, 2012; St. Pierre, 2018). Although Jickling and Reed (2017) do not speak specifically to arts-based research, they acknowledge these challenges by closely attending to multiplicity in their work with the sixth graders. For example, to elicit reflective responses from the sixth graders and to involve them in thinking about the progression of the project, Jickling and Reed projected an "infinitly repeating image of a photograph, within a photograph, within a photograph," (Krstich, 2017, p. 13) image of the children seated in front of the classroom. As a pedagogical project, understanding what the students were gaining through participation required Jickling and Reed to consider the complexity of the sixth graders' experiences over time and space. In addition, wrestling with how to document and represent multiplicity inherent in their work, they presented multiple iterations of their project in the form of chocolate bars, single wrapped chocolates, a poster/book cover with photos of chocolates, artist statements and the book title, Multiple Elementary. 
In the case of Allora and Calzadilla's (2019) Chalk series, the implementation of the project in public spaces, in multiple sites, along with the fluid and unpredictable quality of participation (human and non-human) opened up space for endless unforeseen interactions: between those who sketched out whimsical drawings; others who scratched out messages of political discontentment; those state officials who intervened to confiscate the chalk; the chalk that travelled to other sites on the heels of shoes; and those intra-actions which are unknown. Overtime, the chalk smeared, was washed away by rain, gathered by cracks in the pavement reflecting multiple, plausible versions of the work or traces, which Allora and Calzadilla describe as their medium. According to the artists, "the trace links presence and absence, inscription and erasure, preservation and destruction, and appearance and disappearance" (2019, para. 3) setting up infinite ever-changing iterations or multiples. While Allora and Calzadilla's interest in mark-making inspired Chalk, the series unfolded in countless ways. To a certain extent, the impact of the work lies in the multiple performances that emerged around the chalk, that is, its multiplicity, rather than the fact that social change is taking place. It set in motion the potential for many forms of collective action, the outcomes of which are un/known and (un)resolved.

The works described above raise important questions about the documentation and representation of fluid, collective, and in some cases emergent events which "evolve through a process of performative interaction" (Kester, 2004, p. 10). In reference to Jickling and Reed's Ask Me Chocolate's project, Brown (2017), describes the challenge of "concretizing a series of living gestures" (p. 9) that comprise participatory, pedagogical and performative practices. Helguera too, expresses the difficulty of documenting an intangible social interaction asserting that:

Documentation should be regarded as an inextricable component of an action, one which, ideally, becomes a quotidian and evolving component of the event, not an element of post-production but a co-production of viewers, interpreters and narrators. Multiple witness account, different modes of documentation and most importantly a public record of the evolution of the project in real time are ways to present an event in its multiple angles and allow for multiple interpretations. (2011, p. 76)

Again, one might look to qualitative research for examples of ways that researchers have taken account of multiplicity. For example, polyvocality is often considered to be of importance because it asks researchers to carefully consider participants' interactions with the researchers and ensures that their voices are heard and represented (Tobin \& Davidson, 1990). In the case of decolonizing methodologies, researchers need to include the voices, lived experiences, and perspectives of participants through introspective processes that interrogate positionality and acknowledge the limitations of researcher subjectivity (Lassiter, 1998; Staikidis, 2014; Tuhiwai Smith). Likewise, feminist scholars, who investigate the intersections of gender, race, and class, emphasize the importance of paying attention to what art educator, Karen Keifer-Boyd (2014) refers to as multivocality or the positionality and 
lived experiences of the researcher and participants, as well as the wide array of semiotic registers that inform experiences.

Describing research as a site of struggle, (Staikidis, 2014) advocates for the use of multiple research strategies in the representation of multiple realities. This includes strategies employed in collaborative ethnography, in which the researcher works with what Lassiter (1998) refers to as "consultants," and uses a bricolage approach to research that utilizes multiple available research tools that take into account the "complexity of the lived world" (Kinchleloe, McLaren, \& Steinberg, 2011, p. 168). While this work is useful as a means for engaging participants in research and, to a degree, representing participants voices within the structure of qualitative methods, institutionally formed barriers often exist between the researcher and the researched. Social practice might be both similar/different in this regard, as the desire to shape a collective form requires that the lines between the researcher and the participants are blurred through an attempt to open up an intersubjective space that can only be shaped in concert with others. If taken seriously, compilations emerge, often unknown from the start, and fleeting, the likes of which require equally fluid processes for documenting and representing practice/research/art.

Always in a state of becoming, social practice artists wrestle with how to document and represent the emergent qualities of the work that is intersubjective and collective in nature. Drawing from the work of the Deleuze and Guattari, Irwin and Springgay (2008) offer a/r/tography as an arts-based research methodology that acknowledges the rhizomatic nature of art/teaching/research that is "understood as a critical exchange that is reflective, responsive and relational, which is continuously in a state of reconstruction and becoming something else altogether" (p. 106). Using new materialism as a theoretical lens, Springgay and Zaliwiska (2015) consider how one might invent new ways of thinking through posthumanist research in the context of research-creation. Specifically, they describe how materialist diagramming is used in their research with social practice artists working in schools in Toronto, Canada. Recognizing the limitations of traditional diagrammatic methods associated with qualitative research, they describe in detail how Massami's (2011) concept of pure edging and Barad's (2011) conceptualization of agential cuts can be used as a kind of materialist diagramming that accounts for the ecological complexities of social practice. According to Springgay and Zaliwiska, pure edging required them to pay close attention to "what is not being said, to disjunctions, paradoxes, and contradictions" (p. 139) cutting things together-apart, opened up a discontinuous passage where something new can emerge (Barad, 2011).

While many social practice artists draw from qualitative methods, interestingly enough, it may be artists unfamiliarity with social science research and traditional methodologies that may lead to the deskilling of traditional arts-based research methodologies and a greater attention to multiplicity in inquiry. Artists' capacities to work outside of what is expected and accepted is supported by their willingness to ignore 
"methodological order, linearity and containment which promote hierarchies and increase methodological surveillance and external quality control” (Koro-Ljungberg, 2016, p. 81), and in doing so, perhaps providing new ways of thinking through research that more fully takes into account the nuances of multiplicity and collectivity.

\section{Concluding Remarks}

As demonstrated through my inquiry, socially engaged art is not necessarily informed by critical theory, participatory research, or even post qualitative methodologies, yet intriguing intersections can be found across epistemologies and ontologies. While artsbased research processes can inform social practice, what makes social practice/research distinct is the emphasis placed on relational aesthetics as a quality of social change. Through the making of a living form (not an object), social change can only take shape in concert with others, and therefore is always situational, always in flux and not predetermined. This fluidity offers methodological and representational challenges that require new ways of not only thinking and living through inquiry, but sharing inquiry with people, places, and things. While unpredictability, uncertainty and ambiguity are qualities common to other forms of arts-based research, social interaction brings about an increased level of relational complexity that arises as sole authorship is relinquished, unconventional skills and values emerge, and multiplicity presents diverse possibilities for thinking about and sharing art/research.

At the same time, it seems counter-intuitive to consider social practice a form of artsbased research as to do so may unintentionally bring with it the trappings of research processes that may inadvertently restrict social interaction. Social practice is meant to be open-ended, non-linear, to take on an unruly presence and is built around the inconsistencies and imperfections opened up through social interaction that cannot be preconceived. It is improvisational and risky and unlike other forms of arts-based research comes into existence through shared dialogue and authorship. Interaction, social or otherwise, like art/research, activates new systems, rhythms, and forms and in doing so challenges us to give up on the structures that make art and research apparent and capable of being reproduced. It is interesting to consider: What can be learned from inquiries that open up the hidden methodologies revealed through social interaction? What can they tell us that we don't already know? How can the deskilling of scholars, artists, and educators disrupt, recalibrate, or create new habits of inquiry? Finally, how might collectively-driven scholarship redefine emancipatory goals to include the more than human?

O'Donoghue (2014) offers that new imaginaries for scholarship do not negate prior forms of inquiry, but rather open up "possibilities for articulating how we, as scholars, educators and researchers, make sense of the world with art, and how art connects us with the world while simultaneously creating worlds for us in which to live" (p. 345). Inherent in his proposition is the arts' potential to extend understanding, connect us more deeply with 
the relational intricacies of living in the world and in doing so, support us in the collective reimagining of a more just world. 


\section{REFERENCES}

Allora, J. \& Calzadilla, G. (2019). Allora \& Calzadilla: Chalk. Retrieved from https://walkerart.org/calendar/2019/allora-calzadilla-chalk

Barad, K. (2011). Nature's queer performativity. Qi Parle: Critical Humanities and Social Sciences, 19(2), 121-158. https://doi.org/10.5250/quiparle.19.2.0121

Barad, K. (2007). Meeting the universe halfway: Quantum physics and the entanglement of matter and meaning. Durham, NC: Duke University Press.

Barone, T. \& Eisner, E.W. (2012). Arts Based Research. Thousand Oaks, CA: Sage.

Beuys, J. (1973). I am searching for field character. In C. Kuoni (Ed), Energy plan for the Western man, (pp 21-23). New York, NY: Four Walls Eight Windows.

Bishop, C. (Ed.) (2006a). Participation. Cambridge, MA: The Whitechapel Gallery and MIT Press.

Bishop, C. (2006b). The social turn: Collaboration and its discontents. Art Forum International, 44(6), 178-183.

Bishop, C. (2012). Artificial hells: Participatory art and politics of spectatorship. Brooklyn, NY: Verso Books.

Bourriaud, N. (1998). Relational aesthetics. Dijon, FR: Le press du reel.

Brown, L. (2017). Forward. In H. Jickling \& H. Reed (Eds.), Multiple elementary (pp. 59). London: Black Dog Publishing.

Brydon-Miller, M. \& McGuire, P. (2009). Participatory action research: Contributions to the development of practitioner inquiry in education. Educational Action Research, 17(1), 79-93.

Brydon-Miller, M. K., Maguire, M., Noffke, P. S. \& Sabhlok, A. (2011) Jazz and the banyan tree: Roots and riffs on participatory action research. In N. K. Denzin \& Y. S. Lincoln (Eds.), Handbook of Qualitative Research, (2nd ed.) (pp. 387-400). Thousand Oaks: SAGE. 
Burke, K. J., Greene, S., \& McKenna, M. K. (2016). A critical geographic approach to youth Civic engagement: Reframing educational opportunity zones and the use of public spaces. Urban Education, 51(2), 143-169.

Carpenter II, B. S. (2014). Leading through giving and collaborating: Considerations for socially engaged arts-based practice and collaborative leadership. Visual inquiry: Learning and Teaching Art, 3(3), 307-320.

Cahnmann-Taylor, M \& Siegesmund, R. (Eds.) (2008). Arts-Based research in education: Foundations for practice, ( $1^{\text {st }}$ ed.). New York, NY: Routledge.

Cahnmann-Taylor, M \& Siegesmund, R. (Eds.) (2018). Arts-Based research in education: Foundations for practice, ( $2^{\text {nd }}$ ed.). New York, NY: Routledge.

Debord, G. (1967). Society of the spectacle. New York, NY: Zone Books.

de Certeau, M. (1984). The everyday practice of everyday life. Los Angeles, CA: University of California Press.

Dewey, J. (1897). My pedagogic creed. In L. A. Hickman \& T. M. Alexander (Eds), The essential Dewey (pp. 229-236). Bloomington, IN: Indiana University Press.

Fay, B. (1977). How people change themselves: The relationship between critical theory and its audience. In T. Ball (Ed.), Political theory and praxis (pp. 200-233). Minneapolis, MN: University of Minnesota Press.

Finkelpearl, T. (2013). What we made: Conversations on art and social cooperation. Durham, NC: Duke University Press.

Finley, S. (2014) An introduction to critical research: Demonstrating methodologies and practices of a radical ethical aesthetic. Cultural Studies/Critical Methodologies, 14(6), 531-532.

Finley, S., Vonk, C. \& Finley, M. L. (2014). At home at the school: Critical arts-based research as public pedagogy. Cultural Studies/Critical Methodologies, 14(6), 619625.

Frasz, A. \& Sidford, H. (2017). Mapping the landscape of socially engaged artistic 
practice. Retrieved from

https://www.icasc.ca/resources/mapping-landscape-socially-engaged-artisticpractice-report

Freire, P. (2001). Pedagogy of the oppressed. New York: Continuum. (Original work published in 1970).

Helguera, P. (2011). Education for socially engaged art: A materials and technique handbook. New York, NY: Jorge Pinto Books, Inc.

Holbrook, T., \& Pourchier, N. M. (2014). Collage as analysis: Remixing in the crisis of doubt. Qualitative Inquiry, 20(6), 754-763.

Hultman, K. \& Taguchi, H. L. (2010). Challenging anthropocentric analysis of visual data: A relational materialist methodological approach to educational research. International Journal of Qualitative Studies in Education 23(5), 225-542.

Irwin R. L. \& O' Donoghue, D. (2012). Encountering pedagogy through relational practices. International Journal of Art and Design Education, 31(3), 221-237.

Irwin, R. \& Springgay, S. (2008). Artography as practice-based research. In M. Cahnmannn-Taylor \& R. Siegesmund (Eds.), Arts-based research in education: Foundations for practice, (pp. 103-124). New York, NY: Routledge.

Irizarry, J., \& Brown, T. (2014). Humanizing research in dehumanizing spaces: The challenges. and opportunities of conduction participatory action research with youth in schools. In D. Paris \& M. T. Winn (Eds.), Humanizing research: Decolonizing qualitative inquiry with youth and communities, (pp.63-80). Thousand Oaks, CA: Sage Publications.

Jacobs, M. J. (2018). Pedagogy as art. In G. Sholette \& C. Bass (Eds.), Art as social action: An introduction to the principles and practices of teaching social practice art (pp. 7-10). New York, NY: Allworth Press.

Jackson, A. \& Mazzei, L. (2012). Thinking with theory in qualitative research: Viewing data across multiple perspectives. New York, NY: Routledge.

Jackson, S. (2011). Social works: Performing art, supporting publics. New York, NY: Routledge. 
jagodzinski, J. \& Wallin, J. (2013). Arts-based research: A critique and a proposal. Rotterdam, NL: Sense Publishers.

Jickling, H. \& Reed, H. (Eds.) (2017). Multiple elementary. London: Black Dog Publishing.

Kalin, N. M., \& Barney, D. T. (2014). Hunting for monsters: Visual arts curriculum as a gnostic inquiry. International Journal of Art and Design, 33(1), 19-31.

Kaprow, A. (1966). Assemblages, environments and happenings. New York, NY: Henry N. Abrams.

Keifer-Boyd, K. (2014). Feminist perspectives. In K. M. Miraglia \& C. Smilan (Eds.), Inquiry in action: Paradigms, Methodologies and Perspectives in Art and Research (pp. 67-77). Reston, VA: National Art Education Association.

Kester, G. H. (2004). Conversation pieces: Community and communication in modern art. Berkeley, CA: University of California Press.

Kester, G. H. (2005). Conversation Pieces: The role of dialogue in socially-engaged art. In Z. Kucor \& S. Leung (Eds.), Theory in Contemporary Art Since 1985 (pp. 153165). Mauldin, MA: Blackwell Publishers.

Kester, G. H. (2011). The one and the many: Contemporary collaborative art in the global context. Durham, NC: Duke University Press.

Kincheloe, J., McLaren, P. \& Steinberg, S. (2011). Critical pedagogy and qualitative research: Moving to the bricolage. In N. K. Denzin \& Y. S. Lincoln (Eds.), The Sage handbook of qualitative research (pp. 163-177), Thousand Oaks, CA: Sage Publications.

Knowles, J. G. \& Coles, A. L. (Eds.) (2008). Handbook of the arts in qualitative research: Perspectives, methodologies, examples, and issues. Los Angeles, CA: Sage.

Koro-Ljungberg, M. (2016). Reconceptualizing qualitative research: Methodologies without methodology. Los Angeles, CA: Sage Publications. 
Krstich, V. (2017). Multiple elementary: Leftovers, multiple learning. In H. Jickling \& H. Reed (Eds.), Multiple elementary (pp. 12-21) London: Black Dog Publishing.

Lacy, S. (1995). (Ed). Mapping the terrain: New genre public art. Seattle, WA: Bay Press.

Lassiter, L. E. (2015). The Chicago guide to collaborative ethnography. Chicago, IL: University of Chicago.

Lather, P. (1986). Research as praxis. Harvard Educational Review, 56(3), 257-278.

Leavy, P. (Ed.) (2019). Handbook of arts-based research. New York, NY: Guilford Press.

Leavy, P. (Ed.) (2009). Method meets art: Art-based research practice. New York, NY: Guilford Press.

Manning, E. \& Massumi, B. (2014). Thought in the act: Passages in the ecology of experience. Minneapolis, MN: Regents of the University of Minnesota.

Massami, B. (2011). Semblance and event: Activist philosophy and the occurrent arts. Cambridge, MA: MIT Press.

Meban, M. (2009). The aesthetic process of dialogical interaction: A case of collective art praxis. Art Education, 62(6), 33-37.

O'Donoghue, D. (2014). Art, scholarship, and research: A backward glance. In L. Fleming, L. Bresler, \& J. O'Toole (Eds.), The Routledge international handbook of the art and education (pp. 345-358). Abingdon, UK: Routledge.

Oliver, J. \& Badham, M. (2013). Representing the everyday: Situational practice and ethnographic conceptualism. Laboratorium 5(2), 149-165.

Pasternak, A. (2012). Foreword. In N. Thompson (Ed.), Living as form: Socially engaged art from 1991-201,1 (pp. 7-9). New York, NY: Creative Time Books.

Rousell, D. (2019). Inhuman forms of life: On art as a problem for post-qualitative research. International Journal of Qualitative Studies in Education, 32(7), 887908. https://doi.org/10.1080/09518398.2019.1609123 
Rousell, D. and Fell, F. (2018). Becoming a work of art: Collaboration, materiality and posthumanism in visual arts education. International Journal of Education through Art, 14(1), 91-110. https://doi.org/10.1386/eta.14.1.91 1

Sanders-Bustle, L. (2018). Socially engaged art as living form: Activating spaces and creating new ways of being in a school setting. Art Education, 71(6), 38-44.

Sanders-Bustle, L. (2019). Sketching a social/teacher practice through participation: An imperfect proposition for teacher practicum. Studies in Art Education 60(3), 236-251.

Schubert, L. (2006). Is social work art, or is art social work? The International Journal of the Humanities, 4(5), 43-51. Retrieved from https://doi.org/10.18848/1447-9508/CGP/v04i05/41895

Schlemmer, R. H., Carpenter II, B. S., \& Hitchcock, E. (2017). Socially engaged art education: Practices, processes, and possibilities. Art Education, 70(4), 56-59.

Sholette, G \& Bass, C. (Eds.) (2018). Art as social action: An introduction to the principles and practices of teaching social practice art. New York, NY: Allworth Press.

Springgay, S. \& Zaliwska, Z. (2015). Diagrams and cuts: A materialist approach to research-creation. Cultural Studies/Critical Methodologies, 15(2), 136-144.

Springgay, S. (2013). The pedagogical impulse: Aberrant residencies and classroom ecologies. C Magazine, (119), 16-23. Retrieved from https://cmagazine.com/issues/119/the-pedagogical-impulse-aberrant-residenciesand-classroom-ecolo

Springgay, S., Irwin, R., Leggo, C. \& Gouzouasis, P. (Eds) (2008). Being with a/r/tography. Rotterdam, NL: Sense Publishers.

Staikidis, K. (2014). Decolonizing methodologies and the ethics of representation: A collaborative ethnography with Maya artists Pedro Rafael Gonzalez Chavajay and Paula Nicho Cumez. In K. M. Miraglia \& C. Smilan (Eds.), Inquiry in action: paradigms, methodologies and perspectives in art and research (pp. 67-77). Reston, VA: National Art Education Association. 
St. Pierre, B. A. (2015). Practices for the "new" in the new empiricisms, the new materialisms, and post qualitative inquiry. In N. K. Denzin \& M. D. Giardina (Eds.), Qualitative Inquiry and the Politics of Research, (pp. 75-95), Walnut Creek, CA: Left Coast Press.

St. Pierre, B. A. (2018). Writing post qualitative inquiry. Qualitative Inquiry 24(9), 603608.

Thompson, N. (2012). Living as form. In N. Thompson (Ed.), Living as form: Socially engaged art from 1991-2011 (pp. 16-24). New York, NY: Creative Time Books.

Thorne, S. (2017). School: A recent history of self-organized art education. Berlin, DE: Sternberg Press.

Tobin, J. \& Davidson, D. (1990). The ethics of polyvocal ethnography: Empowering vs. textualizing children and teachers. International Journal of Qualitative Studies in Education, 3(3), 271-283. https://doi.org/10.1080/0951839900030305

Tuhiwai Smith, L (2012). Decolonizing methodologies: Research and indigenous peoples. London, UK: Zed Books.

Wang. C. C. (1999). Photovoice: A participatory action research strategy applied to women's health. Journal of Women's Health, 8(2), 185-192.

Wang, C. C., \& Burris, M. A. (1997). Photovoice: Concept, methodology, and use for participatory needs assessment. Health Education \& Behavior, 24(3), 369-387.

Wang, Q., Coemans, S., Siegesmund, R. \& Hannes, K. (2017). Arts-based methods in socially engaged research practice: A classification framework. Art/Research International: A Transdisciplinary Journal 2(2), 5-39. https://doi.org/10.18432/R26G8P

Whelan, F. (2018). The listening workshop: A two-hour relational encounter that exposes the politics of voice and listening. In G. Sholette \& C. Bass (Eds), Art as Social Action: An introduction to the Principles and Practices of Teaching Social Practice Art, (pp. 33-37). New York, NY: Allworth Press. 